\title{
The Quakers: Forgotten Pioneers
}

\author{
Donncha Kavanagh $^{\mathrm{a}}$ and Martin Brigham ${ }^{\mathrm{b}}$ \\ aniversity College Dublin (UCD), Ireland (e: donncha.kavanagh@ucd.ie) \\ ${ }^{\mathrm{b}}$ Lancaster University, UK, (e: m.brigham@lancaster.ac.uk)
}

Chapter for Peltonen, T., Gaggiotti, H. and Case, P. (eds.) (2017)

Origins of Organizing. Edward Elgar. 


\section{INTRODUCTION}

This chapter argues that there is much to be learned about the origins of organizing through looking back at how the Quakers - who have been largely forgotten and overlooked in management and organization studies' founding narratives - were organized and how they ran their businesses.

The chapter is structured as follows. First, we present a brief description and history of the Quakers (also known as the Society of Friends, or simply Friends) from 1650 to c. 1880 . Even though the Quakers underwent a number of schisms during their history, the various branches share a common ideology, which we summarise. Second, we focus on Quakers' remarkable success in business and commerce, especially during the eighteenth and nineteenth centuries. This success has long been recognized by Quakers themselves and also by historians, even though it is largely absent from the history of management thought. Part of our objective is to better integrate this narrative into management and business history, which we do by describing the Quaker beliefs and practices that seemed to provide the basis for their success in business. We analyze these beliefs and practices in relation to contemporary debates within management and organization studies. Third, we proceed to examine the decline of Quaker businesses from the late nineteenth century onwards, a decline that we link with the rise of managerialism. We argue that the Quakers' absence from the history of management thought is neither an accident nor an oversight, but rather is best understood as a deliberate, political act that benefitted a new managerial elite that emerged out of mid-nineteenth century initiatives in corporate law. We conclude the chapter by reflecting on the lessons which might be learned through studying the Quakers and their approach to management and organization. 


\section{A DISPROPORTIONATE (AND LARGELY FORGOTTEN) INFLUENCE}

At the heart of Quaker thought and practice is the idea that the basis of their faith is a direct relationship and experience of God or the Divine, unmediated by creeds, rituals or a religious hierarchy. Because there is no creed to follow, many Quakers, particularly 'un-programmed Friends' in the UK and US, no longer see themselves as Christians or waiting to be saved by the resurrection of Christ, and so there is now a diversity of non-theist Quakers, Buddhist Quakers, Muslim Quakers, etc. Yet while there are now different branches of Quakerism-Conservative, Liberal, Pastoral, and Evangelical—all Quakers share beliefs that go back to the foundation of the movement in the mid-seventeenth century. This chapter's focus is Quakerism in England, Wales and Ireland from around 1650 to around 1930 and our analysis is focused on the Liberal branch of Quakerism (Navias, 2012:4-11).

Quakerism emerged as a non-conformist religious movement in the political unrest, religious turmoil and civil upheaval of 1650s England—within the period that historians call the 'Century of Revolution'. Founded by George Fox (1624-1691), a shoemaker from Leicestershire, Quakers have always been small in number: in 1680 , when their strength was probably at its height, there were approximately 60,000 in England and Wales (1.15\% per of the population), with the number dropping to $19,800(0.21 \%)$ in 1800 , and $13,859(0.07 \%)$ in 1860 (Wrigley and Schofield, 1989: 92-5). In 2012, the number of Quakers in England and Wales was 13,906 which is almost identical to the 1860 number though the percentage of Quakers in the population has now dropped to $0.02 \%$. Currently there are 1,500 Quakers in Ireland (also $0.02 \%$ of the population). Quakers today number about 360,000 members worldwide. 


\section{QUAKERS, INDUSTRY AND BUSINESS}

Though small in number, many have suggested this relative invisibility belies their historical and contemporary impact, producing a remarkable and disproportionate number of businesspeople, scientists, engaged thinkers, and campaigners for justice, peace and human rights (Furtado, 2013). The British industrial system was based on family owned businesses, an extraordinary number of which were Quaker-owned including many of the largest and most technologically advanced. Table 1 lists some of the more important Quaker companies, most of which were formed in England and Wales. Many of these have now been merged into or acquired by other companies and so their Quaker roots can be easily forgotten. And while other enterprises might not be described as Quaker, members of the Society of Friends played central roles in the formation of major companies like IBM (Belden and Belden, 1962), Sony, Price Waterhouse, and J. Walter Thompson (Windsor, 1980). Quakers have traditionally campaigned for human rights and actively engaged in conflict resolution. For example, Quakers founded Oxfam in 1942, they were awarded the Nobel Peace Prize in 1947, and, from 2001, Elizabeth Fry, the nineteenth century Quaker campaigner for the humane treatment of prisoners, was depicted on the Bank of England $£ 5$ note.

Table 1. Examples of Quaker companies, with date of establishment

\begin{tabular}{|l|l|}
\hline & Company/Family \\
\hline Accounting & Price Waterhouse (1865) \\
\hline Banking & Barclays (1690), Lloyds (1765), Guerney (1775) \\
\hline Biscuits & Huntley \& Palmer (1822), Carr (1831), Jacobs (1851) \\
\hline Brewing & Truman \& Hanbury (1781), Young \& Co. (1831), Burton (1842) \\
\hline Chemicals & $\begin{array}{l}\text { Allen \& Hanbury (1715), Crosfields (1814), Reckitt (1840), Albright } \\
\text { \& Wilson (1856) }\end{array}$ \\
\hline
\end{tabular}




\begin{tabular}{|l|l|}
\hline Chocolate & $\begin{array}{l}\text { Fry's (1761), Huntley \& Palmers (1822), Cadbury (1824), Rowntree } \\
(1862)\end{array}$ \\
\hline Clockmaking & Tompion (1670), Quare (1671), Graham (1738), Huntsman (1740) \\
\hline Glass & Waterford Crystal (1783) \\
\hline Engineering & Ransomes (1789), Baker Perkins (1878) \\
\hline Life Insurance & Friends Provident (1832) \\
\hline Match manufacturing & Bryant \& May (1843) \\
\hline Metals & $\begin{array}{l}\text { Bristol Brass Company (1702), London Lead Mining (1705), } \\
\text { Rawlinson (1720), Huntsman (1740), Ransome (1789) }\end{array}$ \\
\hline Newspapers & News Chronicle (1855) \\
\hline Paper \& Packaging & John Dickinson Stationary (1804), E.S. \& A. Robinson (1844) \\
\hline Pottery \& China & Cookworthy (1730), Champion (1773), \\
\hline Retailing & Laws Stores (1885) \\
\hline Shoemakers & C \& J Clark (1825) \\
\hline Shipbuilding & Swan Hunter (1880) \\
\hline Steelmaking & Consett Iron Company (1864), Stewarts \& Lloyds (1859) \\
\hline Textiles & $\begin{array}{l}\text { Gurney (1683), Were (1686), Barclays (1690), English Sewing } \\
\text { Cotton (1897) }\end{array}$ \\
\hline $\begin{array}{l}\text { Note: Because of mergers, acquisitions and name changes, the dates indicated might be } \\
\text { contested. }\end{array}$ & \\
\hline
\end{tabular}

In the United States, two Presidents—Herbert Hoover and Richard Nixon—were Quakers, though their most famous Quaker is probably the English aristocrat William Penn, a real estate entrepreneur and the founder of Pennsylvania. In the sphere of management, Frederick Taylor was the son of a notable Quaker family in Philadelphia, while Mary Parker Follett and Wroe Alderson (often spoken of as the father of marketing) were active Quakers. It was in this New World milieu that another Quaker, Joseph Wharton, founded America's first business school, the 
Wharton School in 1881 (Baltzell, 1996). Wharton also co-founded and was the major shareholder in Bethlehem Steel Corporation, and employed Frederick Taylor in 1898 with the express purpose of applying more scientific approaches to managing the factory (Copley, 1923).

Quaker businesses were highly innovative and modern and their ongoing commercial success was typically based on the development of new technologies and processes, drawing on the latest scientific advances. Many of the leading botanists and chemists during the eighteenth century were Quakers (Raistrick, 1950/1968). They were also innovative with respect to the management and social aspects of their businesses and were the first — or among the first — to adopt a wide range of business initiatives, as catalogued in Table 2 (drawn from Windsor's (1980) study of Quakers in business).

Table 2. Business innovations pioneered by Quakers

\begin{tabular}{|l|l|}
\hline Marketing & Fixed prices; press advertising. \\
\hline Operations & Vertical integration of extraction, production and distribution \\
\hline Finance & Commercial paper \\
\hline Employee relations & $\begin{array}{l}\text { Adult education on company time; hot meals for employees; housing } \\
\text { for employees to be purchased over time at cost and low interest } \\
\text { rates; workers hostels; pensions; pensions for widows; indexed } \\
\text { pensions; free medical and dental services for employees }\end{array}$ \\
\hline Governance & $\begin{array}{l}\text { Functional department organisation; multidivisional organisation; } \\
\text { participative management; consensus building; works councils; } \\
\text { appeals committees; profit sharing; cooperative ownership; employee } \\
\text { selection of managers. }\end{array}$ \\
\hline Accounting & Formal accounting and auditing \\
\hline R\&D & $\begin{array}{l}\text { Research \& development departments; hiring of university professors } \\
\text { as consultants. }\end{array}$ \\
\hline Banking & Provincial Banking; the cheque; bills of exchange \\
\hline
\end{tabular}


Yet, Quakers have been largely ignored in the management literature and, surprisingly, in the history of management, which typically locates the discipline's origins in the mid to late $19^{\text {th }}$ century, well over a century after most of the Quaker businesses had been founded and at a point when many of these businesses were drifting out of Quaker control. Barley and Kunda (1992) begin their story about the evolution of managerial ideologies in 1870; Eastman and Bailey (1998) start their story in 1890, as does Guillén (1994) when he identified scientific management as the first management model; Shenhav (1995; 1999) begins his study of the (engineering) foundations of organization theory in 1879; Wren (1997: xii) notes that 'about $1880 \ldots$ the literature took a quantum jump as a result of the workshop management movement'; while Towne (1886), one of the first engineers to see management as a new social role for engineers, published his influential article, The Engineer as an Economist, in 1886. Significantly, all of these authors focused on America, which at least partly explains why they overlook the Quakers who were, in the main, located in England, Wales and Ireland.

\section{QUAKERS IN BUSINESS}

We are fortunate because the Quakers, as dedicated and conscientious record-keepers, have left a significant store of documents that give an excellent insight into how they organised as well as their involvement in science, industry and society. In particular, the Quakerism and Industry reports published by the Quaker employers' conferences between 1918 and 1948 (1918, 1928, 1938, 1948) provide a unique record of Quaker debates about business during the first half of the twentieth century. And while they may have been largely overlooked and forgotten in the fields of management and organization studies, numerous books and articles have been written about them. This chapter draws on various texts documenting their involvement in business and science (Emden, 1939; Child, 1964; Walvin, 1997; Roberts, 2004; Freeman, 2013; King, 2014) 
including some authored by Friends themselves (Raistrick, 1950/1968; 1953; Windsor, 1980). The historical record is comprehensive and so only some brief cases will be included, the purpose being to identify salient features.

The Quakers were modernizers in business practice and in their belief in science and technology as emblematic of the rupture of modernity. Consistent with Weber's account of rise of the Protestant ethic and industrialisation, Quakers similarly saw their religious way of life as enacted through worldly affairs and actions, including seeing business as a calling (Freeman, 2013). Hence, they were consistently innovating in business and were quick to experiment with and apply new scientific and engineering ideas and technologies. This interest in experimentation is probably also linked to what is sometimes called their 'experiential Christianity'-i.e., their emphasis on 'inward sacraments' and God in everything in the present moment rather than rituals, creeds and holy books (Navias, 2012: 1). Their scepticism towards authority and received wisdoms—some see Quakerism as a 'religion of uncertainty' (Pym, 1999:137)—also made them ready and willing to formulate and associate themselves with new explanations for the social and natural world, an attribute that aligned them well with the emerging scientific ethos of their time. Hence it is perhaps no surprise that their influence was most important during the $18^{\text {th }}$ and $19^{\text {th }}$ centuries when Britain led the industrial revolution and dominated world trade and commerce in part through science and technology.

One of earliest advances was made by Abraham Darby I who scientifically studied brass production and founded the world's first metallurgy laboratory. In 1709 he developed the cokefuelled blast furnace, which was a seminal moment in the industrial Revolution (1760-1820) as it enabled the production of large quantities of iron that was the raw material for steam engines, bridges, and many of the inventions of the $19^{\text {th }}$ century. Darby and his son, Abraham Darby II, 
made numerous other innovations in metal production while his grandson, Abraham Darby III (1750-1789) implemented various measures to improve the conditions of his workforce, including buying farms to grow food during times of food shortage, building houses for his workers, and paying higher wages than the norm (Raistrick, 1953).

Allen \& Hanbury's was another Quaker business from that period that was also based on the application of science, in this case in the field of pharmacology. The company was founded in 1715 by Silvanus Bevan, a Welsh Quaker, and was successful but unspectacular for many years. However, it was only after the well-known scientist, William Allen, also a Quaker, joined in 1792 that the company really prospered. Allen's nephew, Daniel Hanbury joined the company in 1808 and by the second half of the $19^{\text {th }}$ century the company had large scale operations producing infant food, medicated pastilles, malt preparations, cod liver oil and a variety of pharmaceutical and medical goods with branches and agencies around the world (ChapmanHuston and Cripps, 1954). It was acquired by Glaxo Laboratories in 1958.

A similar slow-burning model of development can be seen in other Quaker companies from that period. For instance, the chocolate manufacturers Fry's, Cadbury and Rowntree's were founded by Quakers in 1761, 1824 and 1862 respectively, and each of these companies was extremely innovative in terms of products, production processes and what would now be called 'human resource strategies' over many decades after their founding. However, the companies only experienced significant growth in the late $19^{\text {th }}$ and early $20^{\text {th }}$ centuries at which point they dominated the confectionary market in the UK.

The Quakers were opportunistic, experimental and willing to take risks, and hence Quaker companies often became quite diversified. For instance, Arthur Darby I was involved in the copper, brass, and iron industries and his innovations ranged from the blast furnace to new 
methods for casting brass items. Isaac Reckitt was another Quaker businessman who initially established a milling business in Boston, then a corn business in Nottingham, and then a starchmaking business in Hull in 1840. This company, Reckitt \& Sons, diversified into black lead, laundry blue, household polish manufacturing, and in the early twentieth century it developed household disinfectants including well-known brands like Dettol and Harpic. Reckitts merged with J \& J Coleman in 1938 and that entity subsequently merged in 1999 with the Dutch company Benckiser NV, eventually becoming RB in 2014.

John Freame (1669-1745) was another Quaker businessman who, as well as being a goldsmith, had interests in the mining of precious metals and the grocery trade. In 1736, his son Joseph took James Barclay as a partner and that partnership became increasingly devoted to banking, eventually becoming Barclays Bank. Similarly, the history of Lloyds Bank began when the Welsh Quaker Sampson I Lloyd (1664-1724) moved to Birmingham in 1698 to avoid persecution-Birmingham was not incorporated and so dissenting preachers were not barred from preaching there. Birmingham was especially tolerant of Quakers and religious dissent, and indeed it has been long associated with the Quakers. Cadbury was based there and, in the late nineteenth century, George Cadbury developed Bourneville as a model village four miles south of the city. Lloyd became an ironmaster and this business thrived to the point that the Lloyd family began to lend money to smaller manufacturers and, following a succession of changes of name and partners, the business eventually became Lloyds Bank. Similar stories abounded which is why, by 1826 , there were at least seventy-four banks founded or owned by Quakers (Walvin, 1997: 2). Not surprisingly, given the strong links between Quakers, Quaker banks often merged with or acquired other Quaker banks. For instance, Barclays Bank dates from 1896 when 20 local banks — all of them Quaker-run — merged to form Barclay \& Co, taking the name 
from their London constituent. Barclay's subsequently acquired two other Quaker banks, J. \& L. W. Pease Bank in 1902 and Gillet's Bank in 1919.

\section{QUAKER BELIEFS}

Any analysis of the Quakers' success in business has to refer to the sect's beliefs and practices that have been persistently reproduced since the Quakers emerged in the mid-seventeenth century. We discuss these beliefs and practices in turn even though they are obviously interlinked. Perhaps their most important belief is that there is 'that of God in everyone,' often referred to as the 'Inner Light'. Believing that there is God in everyone means that each person is of particular interest as an individual, and of equal interest. Hence, the Quaker philosophy is essentially liberal and individualistic but also community focused. They would be opposed to the notion of 'human resource management' as, for them, depicting humans as a resource and as a means to an end of production would be inimical to the idea of individual uniqueness as an end in itself. For similar reasons they were not enamoured with the idea of trade unions because (a) unions are collectivist and (b) unions are premised on the notion that workers' interests conflicted with those of employers, and would therefore necessarily lead to conflict, to which they were fundamentally opposed. More broadly, Quakers did not endorse the socialist tradition because of its focus on collective action, power and social class. Instead, Quaker businesses were characterized by benevolent paternalistic control, coupled with an acute sense of the employer's moral duty to employees instantiated in the type of innovative and extensive welfare benefits identified in Table 2 .

The contention 'that of God in everyone' means that the first Quakers believed that everyone is equal before God. From this belief, traditional distinctions (in language, conduct, dress, for example) were irrelevant, as was hierarchy, formal or paid leadership or ministers, and they saw 
no need for an educated clergy to lead and interpret 'holy' books. Consequently they had no place for creedal formulas or set rituals. Turning to their inner spirit, through a silent waiting and listening, was more important than biblical stories about the past or narratives about salvation in the future. This egalitarian philosophy meant that Quakers were hostile to established authority, and so they would not pay tithes to the church, nor remove their hats to acknowledge superiors, nor swear oaths. For such actions they were persecuted violently from the earliest years, but most especially in the second half of the seventeenth century: by 1660 more than 4000 Quaker men were incarcerated.

This commitment to egalitarianism and individualism has, from the outset, created some tension for Quaker businessmen as they were against the exploitation and profit of one individual at the expense of another, which has traditionally made them uneasy with the morality of business profit. However, this uneasiness did not stop them from engaging in business, even if one Quaker businessman asserted that the 'the title of Quaker employer...[is] a flat contradiction in terms' (Society of Friends, 1938: 23). Instead, it merely spurred those Quakers who went into business to devise and implement a range of democratic structures and processes in the workplace, which have been a feature of Quaker businesses since the seventeenth century (Raistrick, 1950/1968). These structures went as far as recognizing the principle of joint control, with workers taking part in the commercial and financial administration of the business. For example in 1916, Joseph Rowntree (1836-1925)—who owned the chocolate manufacturer Rowntree's that at the time had over 5,000 employees - urged workers to claim a share in industrial decision-making as a 'matter of right' (Child, 1964: 301). Five years later, his son Seebhom (1871-1954) made a similar point stating that, 'It is important that the workers should be consulted and have a share in determining matters which are of real consequence — not merely 
questions of welfare' (Rowntree, 1922: 38). However, in practice it proved difficult to avoid a hierarchical system of authority, especially once the organization reached any level of scale, and so, by 1938 the younger Rowntree was making a somewhat different point: 'No business can be efficiently managed by mass meetings of the workers. The workers must be divided into those whose duty it is to give orders and those whose duty it is to obey them' (Rowntree, 1921/1938: 2).

Even though the Quakers advocated individualism, their moral philosophy was not centred on rational self-interest or egotism. Rather, they believed that if the goodness of each individual is given adequate expression, then the 'inner Light' of each will unite the community in brotherhood and peace. For them, the other person is not a competitor in a Darwinian struggle for survival, but rather another servant of the community. Thus, mutual goodwill is of paramount importance, because, allied to the absence of conflict, it leads inevitably and inexorably to social order and the greater common good: 'Mutual service should be the principle upon which life is organised. Service, not private gain, should be the motive of all work' (Society of Friends, 1918 quoted in Child 1964: 295). The Quaker belief in mutual service has found its most obvious expression in their legendary munificence. For example, Joseph Rowntree and his son Seebohm—described by Lyndall Urwick (1962) as 'the father of British management' - introduced a wide range of employee benefits including a suggestion scheme (1902), a pension scheme (1906), widows' pension (1916), annual holidays with full pay (1918), central works council (1919) and profit sharing (1923) (Vernon and Rowntree, 1958; Barclay, 1995). The bigger Quaker companies also built model factories, with adjoining model villages, and provided medical services, schools, libraries and gymnasia for their workers, long before the 'human relations' movement developed in the 1930s. Consistent with their belief in mutual 
service, Quakers often engaged in philanthropy: Joseph Rowntree, for instance, donated a swimming pool to the City of York and also a public park.

Philanthropy was also in accord with the Quaker belief in the morality of simplicity and plainness and the notion that one should not flaunt one's prosperity. For them, the function of industry is to serve the community as a whole rather than to accumulate personal wealth, which they saw as almost an accidental by-product of their commitment to a traditional puritan way of life that extolled the merits of hard work, careful husbandry of talents and resources, and personal renunciation, all for the service of others. While the Quakers were at odds with the Puritans over matters theological, they still shared the same commitment to hard work and dislike of waste, which aligned them quite well with employers' concerns for efficiency and worker effort. They also shared, especially in the eighteenth century, the Puritan dislike for music-making (too time consuming), visual arts and the stage (exercises in dissimilitude and insincerity), and sports (which tends to alienate the mind from God) (Society of Friends, 1858a: Epistle 1738, p. 221; 1858b: Epistle 1772, p. 11-12). All of these attributes were conducive to the accumulation of wealth, even if this might not have been the Quakers' primary objective.

As often as not, the Quakers were more concerned with social issues, and took prominent roles in various campaigns, such as the fight against slavery, advocating penal reform, initiating new models of industrial welfare, promoting universal education, and caring for the poor. In particular, they were noted for their long-standing interest in pacifism and their abhorrence of war, which can be traced back to their own original experiences of persecution.

The next section focuses on the distinctive Quaker practices - which are of course informed by, and partly constitutive, of their beliefs - that seem to account for some of their business success. 
The early Quakers established a basic organizational structure of local worshiping communities and monthly, regional (quarterly) and yearly meetings for business, which continues to this day. The original structure was essentially Presbyterian, with monthly meetings subordinate to quarterly meetings, which in turn were subordinate to yearly meetings. Today, the Liberal branch of Quakerism does not favour this authority structure and instead sees the monthly meetings as autonomous (Navias, 2012: 11).

From the earliest days in the 1650 s, the term 'Meeting' has been at the very centre of Quaker practice. Nearly every form of interaction is denoted as a meeting. The most important is the meeting for worship which is the central shared experience of Quakers. It is akin to what other denominations might call a church service though there is no role for a priest or minister and meetings are pervaded by silent worship. Meetings are held in meeting houses, which feature no liturgical symbols and are characterized by extreme simplicity. Typically held for an hour on Sunday mornings, a meeting for worship is a gathering of a group of individuals waiting, mostly in silence, for the enlightening and empowering presence of the Divine. If moved to do so, anyone attending the meeting can speak — give vocal ministry — on any subject. Sometimes a meeting comprises a number of vocal ministries on a range of subjects or issues, sometimes one person says or reads something for a few minutes, and sometimes there is silence for the entire meeting.

Corporate decision making occurs through monthly meetings for worship for business which take place after the meeting for worship. Contra conventional understanding, in which we are responsible for what we say, Quakers view decision-making as a process premised upon communal and attentive silence. They distinguish between 'the sense of a meeting' and consensus. Consensus forms of decision-making often involve the integration of differing 
positions within a group and a majority will—as in a democracy. In contrast, Quakers do not vote at meetings, but rather discern the sense of the meeting: agreement is 'sensed' and not voted on (Sheeran, 1983). For Morley (1993: 5), 'Sense of the meeting works because we turn our decision making over to a higher power'. This experiential approach, which dispenses prepared statements, echoes psychoanalytic approaches to group dynamics and some Eastern religions. The process may appear to be inefficient, but its power is its focus on authentic discussion about matters of genuine importance.

This concern with authenticity and honesty underpins not only the Quaker meetings but also their everyday practices including business dealings. Thus the first Quaker shopkeepers would not bargain over prices or put a false price on goods or charge different prices for the same goods as these were all forms of dishonesty. While the market responded positively to these ideas - and made the Quakers rich as a result — the practices were founded on deep ethical beliefs rather than any self-interested calculation of market preferences. Indeed George Fox was disdainful of the rich man, who he saw as the 'greatest thief' because he acquired his wealth 'by cozening and cheating, by lying and defrauding' (Hill, 1991: 28).

This emphasis on honesty meant that from the outset Quakers had a dread of business failure and indebtedness. As early as 1688 Friends were told, through the system of Advices, that none should 'launch into trading and worldly business beyond what they can manage honourably and with reputation; so that they may keep their words with all men...the payment of just debts be not delayed' (Society of Friends, 1802: 195). The Quaker administrative machinery, especially the meetings for business, proved effective in ensuring that Friends actively observed and upheld their principles. For instance, an 'epistle'—a letter from one Friends' body to another-from 1754 exhorted members at monthly meetings 'to be properly watchful over one another, and 
early to caution all against running beyond their depth, and entangling themselves in a greater multiplicity of trade and business than they can extricate themselves from with honour and reputation' (Society of Friends, 1858a: Epistle 1754, p. 290-1). Thus the meetings for business provided a frame for Friends to intervene with advice and help for members in financial difficulty: 'It was assumed that Quakers would turn to each other for business advice; that more experienced heads would help the less so. Co-operation, not rivalry, was their commercial watchword' (Walvin, 1997: 56). If a Friend was in financial trouble or if there were complaints or doubts about debts, poor judgement or business practice, then senior members from a meeting would examine the issue and question those involved. Thus Quaker businesses were subjected to a level of scrutiny and a form of external audit that, in the eighteenth century, did not exist elsewhere in the commercial world.

The Quaker structure of holding local, regional and national business meetings on a regular basis was also important to their business success as it provided a network of trusted personal contacts, friendships and family relationships that could be routinely mobilized for commercial purposes. Quakers could rely on the friendship and hospitality of other Friends as they travelled between the various meetings out of which business relationships and initiatives could emerge. Sharing a history of persecution meant that, even long after the seventeenth century, they were a form of enclave, with strong group affiliation and a relatively small number of powerful norms.

One remarkable and distinctive attribute of the Quakers was their meticulous record-keeping and their passion for writing. For instance, an important feature of their meetings is the writing of minutes, a minute being a statement that captures the sense of the meeting - the decision, action or witness taken by members at a meeting for business. A 'recording clerk' - who has a role akin to a secretary in Roberts' Rules of Order - takes minutes during the business meeting and 
presents them for approval by the group at the meeting. The Quaker fondness for writing and record-keeping is probably because this provided an authentic record of their own struggles and because, having opted out of other formal institutions, they needed to create and maintain their own records. As a result, they devised and implemented a way of tabulating information about themselves that predates the British census system by more than a century. Each meeting has a recorder, who keeps a record of memberships, transfers of memberships, births, deaths and marriages, sending an annual report to the yearly meeting.

Written documents have always played an important part in the way Friends communicate between their various meetings and with one another. In particular, the system of written Advices and Queries is unique to Quakerism and is and was an especially important way of disseminating norms and principles within the community. Queries are questions based on Quaker practices and testimonies that are considered by meetings and individuals as a way of guiding and reflecting on individual and corporate actions. Advices are principles for the guidance of the meeting and its members and published in their book of discipline, Quaker Faith and Practice. As well as Advices and Queries, the book contains regulations on the 'right ordering' of meetings as well as many short quotations collected from the 1650 s onwards that are designed to inspire, challenge and encourage Quakers in their everyday lives and provide questions for reflection.

Quakers were acutely aware, from the outset, that their distinctive beliefs and practices had to taught to and learned by the next generation if their culture was to survive. By 1671, fifteen Quaker schools had been established. From the earliest days, meetings supervised the training of boy apprentices, choosing trades and masters and monitoring progress during the seven years of apprenticeship. Apprenticeships were important in socializing young Quakers into the norms of 
their faith and worked to exclude them from undesirable influences. For instance, when the physician and botanist John Fothergill (1712-1780) started his apprenticeship he signed an indenture agreeing that 'his master well and faithfully shall serve; his secrets shall keep; taverns he shall not haunt; at dice, cards, tables, bowls or any other unlawful games he shall not play' (Fox, 1919: 11). The apprenticeship system was extensive and comprehensive, and, because of their commitment to egalitarianism, Quaker apprentices could aspire to marry their masters' daughters, which many of them did, thus extending the Quaker network.

\section{UNRAVELLING: THE QUAKER AND THE MANAGER}

An intriguing part of the Quaker story is how and why they lost their pre-eminent position in business from the late nineteenth century onwards. Around that time, most of the companies passed out of Quaker ownership and control, and the most famous of these in the UK- such as Cadbury and Barclays — are now only Quaker by historical association.

An important turning point hinges around initiatives in corporate law in the mid-nineteenth century, specifically the Limited Liability Act of 1855, the Joint Stock Companies Act of 1856, and the Companies Act of 1862. Until then, the Quaker companies were essentially family businesses or partnerships, but the limited liability form of ownership, combined with the joint stock company allowed the expansion of the company's capital base beyond family resources, and consequently family control. By the end of the century many of the big Quaker businesses had converted to this corporate form: Reckitt's in 1888, Crosfield's in 1896, Rowntree's in 1897 and Cadbury in 1899. The profound impact of the changes in corporate law is probably much easier to see retrospectively than it was by Quakers at the time, even though those attending the Quaker employer conference in 1918 seemed quite agitated by issues around industrial authority and ownership (at which point ownership had often already changed hands). However for us, the 
willingness of the Quaker companies to embrace the new corporate form was consistent with their enthusiasm for innovation - whether these be technological, organizational, managerial or new forms of governance and corporate ownership — and with their readiness to do what they perceived to be for the greater good, even if this was not in their own self-interest.

And there were some rather obvious reasons why things needed to change. In particular, the large scale of these companies created a requirement for an authority structure and division of labour that was at odds with the Quakers' anti-authoritarian and egalitarian philosophy. For example, the chairman of Cadbury Brothers, Edward Cadbury, at the 1928 Conference on Quaker Employers, while agreeing that 'the worker ought to have some voice in the management of ...industry', was of the view that there was 'no way in which he can be given any effective control in large scale industry' (quoted in Child (1964: 301)). Moreover, as their businesses became larger, managers had to be recruited and these tended not to be Quakers.

The Quaker owners of the early twentieth century were well aware of Taylor's ideas on scientific management, and indeed Edward Cadbury (1914), wrote a detailed critique of the approach, highlighting what he saw as its problems and presciently advocated a position that was very aligned with the human relations approach that only flowered decades later. At the same time, Cadbury had already implemented elements of Taylor's system (Rowlinson, 1988), which is unsurprising given that Quakers disliked waste just as much as Taylor and his followers. Indeed Rowlinson's (1988) detailed historical study shows that Cadbury was an early adopter of scientific management. This is a telling because it reminds us that when it came to managing their businesses, the Quakers were far from doctrinal about their beliefs or practices, such as their particular form of meeting, their anti-authoritarianism, and the like. 
What seems clear is that by 1914, at the beginning of World War One, the Quaker business philosophy was unravelling. One important reason was because there were simply fewer Quakers in business. Some left because of the rigorously high standards of their beliefs, while the accumulation of wealth made it difficult for others to live according to simple values. Additionally, in Britain from the 1870s Quakers were no longer excluded from universities and the professions. As part of this, there was also a shift in rhetoric in the inter-war years from renunciation and industrial democracy to the more ambiguous notion of 'service,' which came to be defined as the employer's duty to maximize business efficiency. The enclave culture, with its strong network and group ethos, also weakened as persecution and discrimination became distant memories and as successive generations assimilated into British upper middle and upper-class society. Others presumably became disenchanted with some old Quaker beliefs, such as the traditional puritan disdain for play, games, and theatre.

Business and commerce also seemed to lose their attraction to those espousing Quaker values. This was partly because, after the 1920s, business theory and practice became more aligned with Quaker beliefs, as evidenced by the shift from naive understandings of efficiency gains to a deeper concern with the worker and the conditions of work. Quaker beliefs were also moving around the same time. For instance, by the 1930s a strong argument was being made within the Quaker community that worker welfare and social ills, such as unemployment, were best addressed by pursuing managerial goals - through industrial efficiency, rationalization and scientific management — rather than welfare policies or religious utopianism, which could be dismissed as 'pious sentimentalism' (Child, 1964: 299). What we see here is that those most committed to the ideals of Quakerism saw business as essentially a means to a social end, and if that end could be achieved through different means then moving out of business was appropriate 
and necessary. Increasingly, Quakers left commerce and instead turned to the public service professions like teaching, social work and medicine. This shift can be seen in microcosm in the case of the industrialist, management thinker and chocolatier, Seebohm Rowntree, who became better known for his comprehensive and influential studies of the poor in York.

Not surprisingly, as Quakers vacated the business boardrooms, the locus of power shifted to a new managerial elite, who were usually more concerned with organizational efficiency and had little concern with welfare and social reform. For their part, the Quakers seemed happy enough to cede power and authority to these new professional managers. For instance, the 1928 Conference on Quaker Employers stressed that, 'whoever is selected as likely to take a leading place (in industry) eventually should undergo a carefully thought out course of education and training ... The old idea that a son, whatever his qualifications, naturally follows his father cannot now be accepted' (Society of Friends, 1928: 90). Again, this willingness to accept new modes of managing business enterprises was consistent with Quakers as modernizers and innovators, and with their willingness to pursue the greater good even at their own loss.

\section{WHAT MIGHT BE LEARNT FROM THE QUAKERS?}

History is always particular and contingent and so one should be cautious about drawing general conclusions from a historical study. Yet, the story of Quakers and business should at least help us problematize some of our assumptions and favoured narratives. Not least, Quakers and business should be better integrated into the history of management thought, and a salient question is why they have been largely excised from dominant narratives. Why, for instance, do management textbooks routinely set the beginnings of the field somewhere between 1870 and 1890 , with everything before that, including the profound contribution of the Quakers to business and commerce, largely dismissed? One answer would be that the corporation as a legal entity 
emerged in the second half of the nineteenth century, and with it a managerial elite that, in large part, was constituted to attend to the corporation's needs, which were never aligned with Quaker aspirations and objectives. Excising the Quakers from the narrative was, from this perspective, both appropriate and necessary. It is perhaps timely that this be now redressed given the deep concern about the undue power of the contemporary corporation (Bakan, 2004; Veldman and Parker, 2012; Veldman and Willmott, 2013), and debates about alternative ways of organizing (Parker et al., 2014).

The Quaker story also problematizes other important narratives in management thought, especially those framed around dualisms. For instance, whatever merits Barley \& Kunda's (1992) highly cited paper has in describing how American managerial discourse has, since 1870, oscillated from normative to rational poles in 30-year waves, it certainly does not map onto the Quaker narrative, as they were consistently concerned with improving, through scientific methods, their business operations and with understanding workers' emotions. As Cadbury put it in his critique of scientific management: 'we are dealing not with inanimate things, but with men and women, with all their physiological and psychological needs and possibilities, as well as prejudices and social sympathies. Even if on the productive side the results are all that the promoters of scientific management claim, there is still the question of the human cost of the economies produced' (Cadbury, 1914: 101). Similarly, the Quaker companies were good examples of so-called 'ambidextrous organizations' (March, 1991; Tushman and O'Reilly, 2006) in that they carefully exploited past successes through good husbandry and prudent management and at the same time their commitment to innovation and experimentation meant that they were explorers. Underpinning this ability to simultaneous explore and exploit was their patience in 
recognizing that success was more typically achieved over generations. In this respect, Quaker in business is a useful counterpoint to shorter-term studies of organisational prowess.

There is also a compelling counter to other dominant models in the management literature, such as Porter's (1980) argument that businesses should not be 'stuck in the middle' between a cost and differentiation strategy. The Quakers show that doing both is viable, and viable over the longer term. Yet the Quakers provide support from one of Porter's other ideas, namely his notion that a geographic concentration of related businesses, suppliers and associations can create a competitive advantage for a region or nation (Porter, 1991). Surprisingly, location is largely excised from most management theory, which is what makes Porter's rather obvious notion of business 'clusters' distinctive. Quaker in business provides examples of such clusters that, while well documented by Quakers and historians, are largely unknown within the business strategy literature (see Sleapwood, 2017). In particular, it also sheds light on the business practices, such as their structure of meetings and the unique form of oversight and auditing within the Quaker network, that supported these enduring clusters.

Our argument also provides an alternative perspective on Shenhav's study of the 'discourse of uncertainty,' that underpins scientific management, human relations and systems rationalism in that each of these approaches is driven to reduce uncertainty (Shenhav, 1999: 198-203; Shenhav and Weitz, 2000). What our study shows is that the roots of the uncertainty discourse go much further back than the American engineers of the late nineteenth century. The Quakers, as moderns, were always engaged with uncertainty and this formed the basis for their relationship in science, engineering and technology qua experimentation. Hence, we would contrast Shenhav's assertion that 'the fact that both the "practice" and "theory" of management can be traced back to the same origin: the systematization project during the period 1880s-1930s' 
(Shenhav, 1999: 199, emphasis added) by highlighting that the 1880s-1930s was precisely the period when the Quakers lost or ceded control of their businesses. Not coincidentally, it was the period when a managerial elite emerged, and when the origins of management theory and practice came to be asserted.

The Quaker belief in plainness, brevity and silence was a reaction to what they saw as the 'Babelish confusion' of religion in mid-seventeenth century England (Bauman, 1983: 1). This confusion (albeit not religious) exists today, with an excess of language, information, constructs, and theories, a phenomenon in which academia has played a not insignificant role. Ghoshal (2005) puts it bluntly: 'By propagating ideologically inspired amoral theories, business schools have actively freed their students from any sense of moral responsibility' (p. 79), which then leads to bad management practices. If there is a contemporary 'Babelish confusion' then a neoQuaker response might be expected as the Quakers seem to provide a coherent and compelling model of how business might be organized for the greater good of communities and society. At the very least, Quaker history, beliefs and practices provide a unique lens for understanding contemporary responses to information overload, confusion and what Ghoshal refers to as 'ideology-based gloomy vision’.

Yet, we should not romanticize the Quakers. They were of their time and some of their practices to business would be seen as paternalistic today. While many of their beliefs might be compelling and laudable, any belief, taken to the extreme, can become repugnant, destructive, paradoxical or a combination of these. For instance, it is arguable that part of the reason the Quakers went into decline was because of their excessive concern with authenticity. Similar to the Puritans, they valorized honesty and integrity and hence disliked acting and lawyers, which they saw as an inauthentic form of behaviour. This puritan pursuit of authenticity also meant 
that they disapproved of play unless it had a utilitarian benefit. For instance the 1738 Yearly Meeting complained of 'particularly balls, gaming-places, horse-races, and playhouses' (Society of Friends, 1858a: Epistle 1739, p. 227). As Huizinga (1955) has made clear, play is foundational to the human condition, is central to understanding ourselves and our world, and is necessary for civilization. He argues that war, religion, sports and the arts are all forms of play and that we should see treat play seriously rather than see is as trivial: 'Play cannot be denied. You can deny, if you like, nearly all abstractions: justice, beauty, truth, goodness, mind, God. You can deny seriousness, but not play' (Huizinga, 1955: 3). The history of the Quakers suggests that in failing to recognize this truth within their belief system, they necessarily compromised their pursuit of authenticity. In looking to the future, what we perhaps need is a philosophy of organizing that believes in authenticity and in play, and a set of practices that is founded on a morality that at once privileges the experiential moment, and the longer term good of future generations. 


\section{REFERENCES}

Bakan, Joel (2004), The corporation : the pathological pursuit of profit and power. New York: Free Press.

Baltzell, E Digby (1996), Puritan Boston and Quaker Philadelphia. New Brunswick, N.J.: Transaction Publishers.

Barclay, Alan (1995), 'The rise and fall of the Friends', Management Today, (1 February): 52-58. .

Barley, Stephen R. and Kunda, Gideon (1992), 'Design and Devotion - Surges of Rational and Normative Ideologies of Control in Managerial Discourse', Administrative Science Quarterly, 37(3): 363-399.

Bauman, Richard (1983), Let Your Words be Few: Symbolism of Speaking and Silence Among Seventeenth-century Quakers. Long Grove, IL: Waveland Press.

Belden, Thomas Graham and Belden, Marva Robins (1962), The lengthening shadow : the life of Thomas J. Watson. Boston: Little, Brown.

Cadbury, Edward (1914), 'Some principles of industrial organisation: The Case For and Against Scientific Management', The sociological review, 7(2): 99-117.

Chapman-Huston, Desmond and Cripps, Ernest Charles (1954), Through a city archway; the story of Allen and Hanburys, 1715-1954. London: J. Murray.

Child, John (1964), 'Quaker employers and industrial relations', The Sociological Review, 12(3): 293-315.

Copley, Frank Barkley (1923), Frederick W. Taylor: father of scientific management. New York: Harper and Brothers.

Eastman, Wayne and Bailey, James (1998), 'Mediating the Fact-Value Antinomy: Patterns in Managerial and Legal Rhetoric, 1890-1990', Organization Science, 9(2): 232243.

Emden, Paul Herman (1939), Quakers in Commerce. London: Low.

Fox, R. Hingston (1919), Dr. John Fothergill and his friends: chapters in 18th century life. London: Macmillan \& Co.

Freeman, Mark (2013), 'Quakers, Business and Philanthropy', in S. W. Angell and P. Dandelion (eds.) The Oxford Handbook of Quaker Studies. Oxford: Oxford University Press, pp. 420-433.

Furtado, Peter (2013), Quakers. Oxford: Shire Publications.

Ghoshal, Sumantra (2005), 'Bad management theories are destroying good management practices', Academy Of Management Learning \& Education, 4(1): 75-91.

Guillén, Mauro F. (1994), Models of management: work, authority, and organization in a comparative perspective. Chicago: University of Chicago Press.

Hill, Christopher (1991), 'Quakers and the English Revolution', in M. Mullett (ed.) New Light on George Fox, 1624-1691. York: The Ebor Press.

Huizinga, Johan (1955), Homo Ludens: A Study of the Play Element in Culture. Boston, MA: The Beacon Press.

King, Mike (2014), Quakernomics : an ethical capitalism. London: Anthem Press. 
March, James G. (1991), 'Exploration and exploitation in organizational learning', Organization Science, 2(1): 71-87.

Morley, Barry (1993), Beyond consensus : salvaging sense of the meeting. Wallingford, PA: Pendle Hill.

Navias, Mathilda (2012), Quaker Process: for Friends on the Benches. Philadelphia: Friends Publishing Corporation.

Parker, Martin, Cheney, George, Fournier, Valerie and Land, Chris (eds.) (2014), The Companion to Alternative Organization. London: Routledge.

Porter, Michael E. (1980), Competitive strategy : techniques for analyzing industries and competitors. New York: Free Press.

Porter, Michael E. (1991), The Competitive Advantage of Nations. New York: The Free Press.

Pym, Jim (1999), Listening to the light: how to bring Quaker simplicity and integrity into our lives. London: Rider.

Raistrick, Arthur (1950/1968), Quakers in science and industry : being an account of the Quaker contributions to science and industry during the 17th and 18th centuries. New York: Kelley.

Raistrick, Arthur (1953), Dynasty of iron founders; the Darbys and Coalbrookdale. London: Longmans.

Roberts, Helen (2004), 'Friends in Business: Researching the History of Quaker Involvement in Industry and Commerce', Quaker Studies, 8(2): 172-193.

Rowlinson, Michael (1988), 'The early application of scientific management by Cadbury', Business History, 30(4): 377-395.

Rowntree, B. Seebohm (1921/1938), The human factor in business : further experiments industrial democracy. [S.I.]: Longmans, Green.

Rowntree, B. Seebohm (1922), Industrial unrest : a way out. London: Longmans, Green \& Co.

Sheeran, Michael J. (1983), Beyond majority rule: voteless decisions in the Religious Society of Friends. Philadelphia: Philadelphia Yearly Meeting of the Religious Society of Friends.

Shenhav, Yehouda (1995), 'From chaos to systems: The engineering foundations of organization theory, 1879-1932', Administrative Science Quarterly, 40(4): 557-585.

Shenhav, Yehouda (1999), Manufacturing Rationality: The Engineering Foundations of the Managerial Revolution. Oxford: Oxford University Press.

Shenhav, Yehouda and Weitz, Ely (2000), 'The roots of uncertainty in organization theory: A historical constructivist analysis', Organization, 7(3): 373-401.

Society of Friends (1802), Extracts from the Minutes and Advices of the Yearly Meeting of Friends held in London. London: Society of Friends.

Society of Friends (1858a), Epistles from the Yearly Meeting of Friends, I. London: Society of Friends.

Society of Friends (1858b), Epistles from the Yearly Meeting of Friends, II. London: Society of Friends.

Society of Friends (1918), Foundations of a True Social Order. London: Society of Friends. Society of Friends (1928), 'Quakerism and Industry'. in J. E. Hodgkin (ed.) Report of the 
Conference. London, Quaker Employers Conference. Friends Book Centre. Society of Friends (1938), 'Quakerism and Industry'. in H. G. Tanner (ed.) Report of the Conference. London, Quaker Employers Conference. Friends Book Centre.

Towne, Henry R. (1886), 'The Engineer as an Economist', Transactions, the American Society of Mechanical Engineers, 7: 428-432.

Tushman, Michael L. and O'Reilly, Charles A. (2006), 'Ambidextrous Organizations: Managing Evolutionary and Revolutionary Change', in D. Mayle (ed.) Managing innovation and change. 3rd ed. London: Sage Publications, pp. 170-184.

Urwick, Lyndall F. (1962), 'The Father of British Management', The Manager, (February): $42-43$.

Veldman, Jeroen and Parker, Martin (2012), 'Specters, Inc.: the elusive basis of the corporation', Business and Society Review, 117(4): 413-441.

Veldman, Jeroen and Willmott, Hugh (2013), 'What is the corporation and why does it matter?', M@n@gement, 16(5): 605-620.

Vernon, Anne and Rowntree, Joseph (1958), A Quaker Business Man. The life of Joseph Rowntree, 1836-1925. London: George Allen \& Unwin.

Walvin, James (1997), The Quakers : money and morals. London: John Murray.

Windsor, David Burns (1980), The Quaker enterprise: Friends in business. London: Muller. Wren, Daniel A. (ed.) (1997), Early management thought. Aldershot: Dartmouth. Wrigley, E. Anthony and Schofield, Roger (1989), The population history of England, 1541-1871 : a reconstruction. Cambridge Cambridge University Press. 